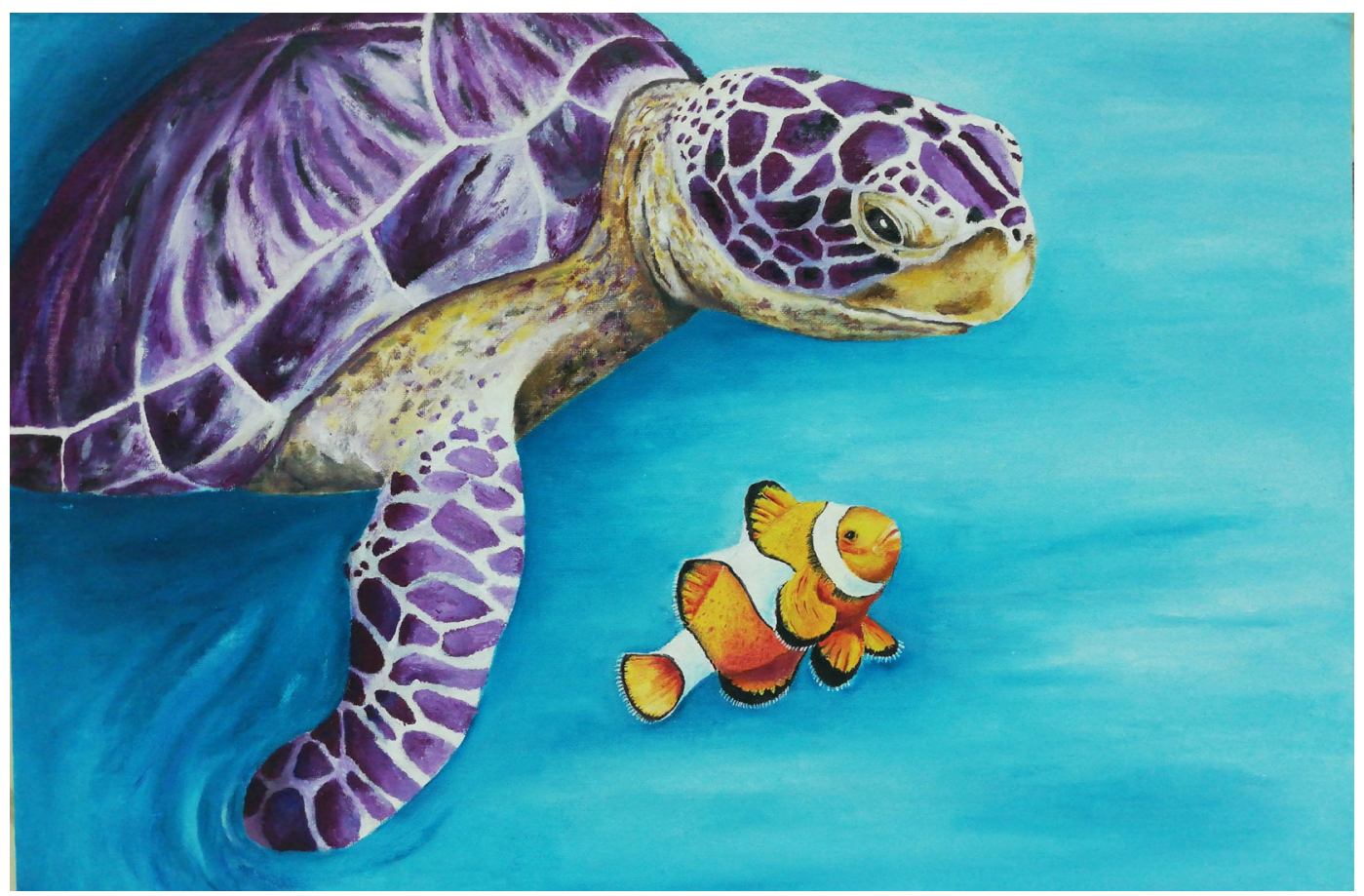

\title{
Nadando en calma
}

\section{Reflexión}

El mar me calma, sus animales me intrigan; pero sus profundidades me asuntan desde un lugar donde no hay playa. El no tenerla me hace desearla más. El pintarla me reconforta; inventarme sus colores me hace feliz. La necesidad de buscar imágenes, colores y sensaciones agradables me hacen pintar, y en esta ocasión buscar refugio en el mar.

\section{Autora}

Telma Barrantes. Docente en la Universidad de Extremadura.

Estudios en: Universidad Autónoma de Madrid y Universidad de Granada.

Máster en Arteterapia y Licenciada en Bellas Artes.

Arteterapia: papeles de arteterapia y educación artística para la integración social.

Monográfico: Las miradas del arte y el arteterapia en tiempos de la Covid19. ISSN-e: 1988-8309 https://dx.doi.org/10.5209/arte.75907 